\title{
"Hell... unless they repent of their sins and turn to God": The problem of Bible translation and the potential impacts of Israel Folau's comments on Māori and Pasifika minority sexualities
}

...I have watched the literal Bible be quoted to justify racial segregation, to ensure the continued sexist oppression of women by the Christian church, and to perpetuate a killing homophobia in our corporate life.

Had I lived in an earlier part of history, I would have seen the Bible quoted to condemn Copernicus, who asserted that the sun did not occupy the center of the universe, and Galileo, who said that the sun did not rotate around the earth. I would have seen the insights of Isaac Newton challenged by the biblical view of God that could only be described as supernatural magic. I would have witnessed the church's attack upon Charles Darwin in the name of a brand of creationism that today is totally dismissed. Perhaps worst of all, I would have watched while religious people appealed to the literal text of the Bible to support the most inhumane treatment of fellow human beings - the institution of slavery. 
The Right Reverend John S. Spong (cited in Helminiak, 2000, p 11)

On 4 April 2018, Israel Folau was asked a question on Instagram by a person that he did not know. The question asked what God's plan for gay people was. Folau responded by proclaiming that homosexuals were destined for "[h]ell... unless they repent of their sins and turn to God" (Robinson, 2018, n.p.). Following the stir that was caused by his remarks, Folau (2018) published an online article titled, I'm a sinner too. Here, Folau (2018) justifies his position against homosexuality - and indeed all transgressions outlined in the Apostle Paul's admonition to the people of Corinth - by quoting 1 Corinthians 6:9-10. He also makes a number of confessions about the sins of his own life, making sure to mention that he repents for these daily. He assures readers that he is not in a position to judge the lives of others and that only God may do that.

Folau (2018) argues that quoting scripture, though sometimes difficult to hear by those resistant to the truth, is beneficial to others in the sense that it might save them spiritually. With regard to the person who posed the question about God's plan for gay people, Folau (2018) writes: "I believed he was looking for guidance and I answered him honestly and from the heart" (n.p.). With an uncompromising faith in his version of Christianity based on literal understandings of the Bible that lack any critical or scholarly consideration, Folau (2018) believes that the Bible contains the infallible truth and says: "I would sooner lose everything - friends, family, possessions, my football career, the lot - and still stand with Jesus, than have all of those things and not stand beside Him" (n.p.).

The Bible is fallible. To understand and interpret its contents requires years of theological training, a working knowledge of some or all of the biblical languages, and a familiarity with the history, politics, religions and cultures of the lands from which the various parts, which now make up the Bible, originated. This is a major undertaking for trained theologians, let alone 
well-meaning and highly influential sports stars. I will argue that literal understandings of the Bible, by the untrained, are problematic, and that the conclusions drawn from inexpert readings of the Bible are, in fact, not only misleading, but dangerous. Indeed, Spong's statement above provides examples of how literal interpretations of the Bible text have led to, and can lead to further, oppression. Folau's recent comments, often described by the media as homophobic, have generated a number of responses from Māori and Pasifika people, some of which will be discussed here.

I am not a trained theologian. I am merely as neophyte in the academic world. However, my intention here is not to profess expertise in theology, but to argue against unscholarly opinions on biblical matters and to briefly demonstrate the complexity of biblical translation and its implications. Furthermore, it is my intention to weave together a number of responses from Māori and Pasifika commentators who have resisted Folau's sentiments.

\section{The complexities of biblical translation: Why the 'average Joe' (or sports star) is incapable}

Bible translation is a difficult task for expertly trained, qualified theologians. It is a scholarly task that, like any professional discipline, requires years of university study and experience in the field. One would call upon the services of a lawyer to speak on issues regarding law, and on specific law experts for specific areas of law. Similarly, if a medical opinion is required, one would turn to a medical professional, or to a specific specialist in a particular field of medicine. With regard to the Bible, theologians are the experts. There are theologians who specialise in different types of theology. Some are experts in the Old Testament or the New Testament. Some are experts in particular fields of theology such as contextual theology or practical theology. Like lawyers and medical doctors, theologians are the experts to whom we should turn when we 
require further understanding on theological issues. Those who read and interpret the Bible without professional training, are like those who read law papers and medical journals without proper training. We may draw some inspiration from these basic readings, but we cannot be experts in them without the proper training, credentials and background knowledge.

To support his position that gay people will go to hell if they do not repent and turn to God, Folau (2018) quotes the English Standard Version, a version that Peters (2018) calls "the Bible as some people wished God had written it" (n.p.), of 1 Corinthians 6:9-10:

9 Or do you not know that the unrighteous will not inherit the kingdom of God? Do not be deceived: neither the sexually immoral, nor idolaters, nor adulterers, nor men who practice homosexuality, ${ }^{10}$ nor thieves, nor the greedy, nor drunkards, nor revilers, nor swindlers will inherit the kingdom of God (emphasis added).

Loader (2010) notes that since the New Testament was written in Greek, being able to read and understand Greek is advantageous with regard to understanding the contents and context of New Testament writings. Helminiak (2000) and Peters (2018) argue that 1 Corinthians 6:9 relies on the translation and

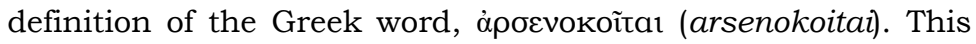
term is made up of two words: arseno-male; and koitai - a word that refers to a bed or bedroom and specifically to having sex with someone (Helminiak, 2000). More accurately, Helminiak (2000) argues, koitai refers to the active partner, or in other words, the penetrator.

The word arsenokoitai also makes an appearance in 1 Timothy 1:10. Helminiak (2000) argues that like 1 Corinthians 6:9, 1 Timothy 1:10 relies on the translation and definition of arsenokoitai. The English Standard Version of 1 Timothy 1:9-10 states: 
9 understanding this, that the law is not laid down for the just but for the lawless and disobedient, for the ungodly and sinners, for the unholy and profane, for those who strike their fathers and mothers, for murderers, 10 the sexually immoral, men who practice homosexuality, enslavers, liars, perjurers, and whatever else is contrary to sound doctrine (emphasis added).

Peters (2018) notes that this is the very first time that the word - he uses arsenokoites, a form of arsenokoitai - was used in any Greek literature. He states:

The word Paul uses here (that Folau's translation has as "men who practice homosexuality") is áoбvokoĩtaı (arsenokoites). First important point: this occurrence in Paul's letter to Corinth is the FIRST TIME this word ever occurs in Greek literature. Ever! Maybe Paul didn't make the word up - maybe it was used by people in conversations - but as there is no earlier usage in writing, we have no idea from that what the word means. It is only used once more in the New Testament (1 Tim $1: 10)$, and the usage there is no help at all to trying to work out what St Paul might mean by this neologism (Peters, 2018, n.p.).

Boswell (1980, 1994), who argues that Christianity was essentially indifferent to homosexuality up until the late Twelfth Century, proposes that the word arsenokoitai refers to male prostitutes who were available for sex with either men or women. Countryman (1988) also maintains that arsenokoitai refers to male prostitution but more precisely to those male prostitutes who targeted older men to gain an inheritance. 
Helminiak (2000) contends that if the word arsenokoitai does, in fact, refer to male prostitution, that the problem lies not in the act of having sex - with either the same or the opposite sex - but with a particular type of prostitution that has "...something to do with sexual foul play around money" (p. 110). Scrogg (1983) agrees that arsenokoitai refers to prostitution but limits the definition to sex between males, and in particular, pederasty.

Different versions of the Bible translate the Greek words into English in different ways. In 1 Corinthians 6:9-10, arsenokoitai is translated in the following ways:

\begin{tabular}{|l|l|}
\hline Bible version & Translation of arsenokoitai \\
\hline King James & $\begin{array}{l}\text { Abusers of themselves with } \\
\text { mankind }\end{array}$ \\
\hline New International & Homosexual offenders \\
\hline New King James & Sodomites \\
\hline Revised Standard - 1952 & Homosexuals \\
\hline Revised Standard - 1977 & Sexual perverts \\
\hline Revised Standard - 1989 & Sodomites \\
\hline Jerusalem Bible & Sodomites \\
\hline
\end{tabular}

(Adapted from Cannon, 2005).

Arsenokoitai, as found in 1 Timothy 1:9-10, for example, is translated in various versions of the Bible in the following ways:

\begin{tabular}{|l|l|}
\hline Bible version & Translation of arsenokoitai \\
\hline King James & $\begin{array}{l}\text { Them that defile themselves } \\
\text { with mankind }\end{array}$ \\
\hline New International & Perverts \\
\hline New King James & Sodomites \\
\hline Revised Standard & Sodomites \\
\hline New English Bible & Perverts \\
\hline
\end{tabular}

(Adapted from Cannon, 2005). 
Scrogg (1983) states that the term malakoi, translated in some versions of the Bible as effeminate, refers to the passive young boy (in a pederastic relationship), and that arsenokoitai and malakoi - a word that essentially means soft $t^{1}$, as found in the Greek version of 1 Corinthians 6:9, are paired words referring to this relationship. The word malakoi has been translated in different ways in different versions of the Bible, thusly:

\begin{tabular}{|l|l|}
\hline Bible version & Translation of malakoi \\
\hline King James & Effeminate \\
\hline New International & Male prostitutes \\
\hline New King James & Homosexuals \\
\hline Revised Standard - 1952 & Homosexuals \\
\hline Revised Standard - 1977 & Sexual perverts \\
\hline Revised Standard - 1989 & Male prostitutes \\
\hline Jerusalem Bible & Calamites \\
\hline
\end{tabular}

(Adapted from Cannon, 2005).

Helminiak (2000) maintains that other scholars have also written about the two words as a pair - one that generally condemns homogenital behaviour. However, malakoi, Helminiak (2000) argues, does not contain any specific reference to homogenital behaviour, making the pairing of the word with arsenokoitai incorrect.

Peters (2018) provides some discussion about the possible meaning and origins of the word arsenokoitai (arsenokoites). He asserts:

The best scholarly guess is that Paul made up the word by combining two words, "male" (öponv) and "bed" (кoitᄁ) from a sentence in the Greek

The word malakoi, defined by Loader (2010) as soft, when applied to men, was generally used pejoratively as a means of signifying effeminacy, and was considered an insult (Elliot, 2004; Jewett, 2007; Martin, 2006). 
translation of the Old Testament (the Septuagint) that he was using:

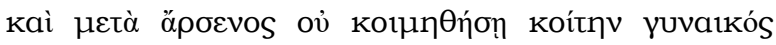

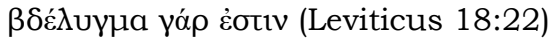

There is no use of arsenokoites in those early centuries after the New Testament to mean homosexual activity. In fact, arsenokoites is used to describe the sexual relationships of men and their wives (Jonannes Jejunator, 6th century). And whenever, in those centuries, writers explicitly write about homosexual activity, they do not use arsenokoites.

Only in the 13th Century, long past the word's common usage - if there was one does arsenokoites become used by some people to describe homosexual activity.

The English Bible does not use the word "homosexual" until 1946, and even then, not for this verse. The first English Bible to use the word "homosexual" in this verse was the 1971, the Living Bible, a paraphrase by Kenneth N. Taylor and not a translation from the Greek at all.

In case readers now point to Leviticus 18:22 (the possible origin of Paul's neologism), ripping it out of context and oversimplifying translation principles - let me emphasise that, again, the best scholarly guess for that complex verse is an admonition against pagan sexual worship practices and shrine prostitution (Peters, 2018, n.p.).

Boswell (1980) argues that Paul distinguishes between homosexual and heterosexual men, and that Paul aimed his discourse at heterosexual men who were engaging in homosexual acts. For Boswell (1980), Paul would not have been offended by homosexual men engaging in homosexual acts, as 
for them, this would have been natural. On the contrary, however, heterosexual men involved in homosexuality, would have been for Paul, very offensive indeed (Boswell, 1980). Loader (2010) argues that scholarly responses to Boswell's argument, claiming that Paul would not have been aware of such categories, have had to be reconsidered in light of new evidence extracted from magical traditions, philosophy, medicine and astrology, exposed by Brooten's (1996), Love between women: Early Christian responses to female homoeroticism. Here, she contends that many people, during Paul's time, were conscious of women and men whose were sexually attracted to their own sex, including lifelong same-sex pairings (Brooten, 1996).

The discussion above about the meaning of the word arsenokoitai reveals a little about the great difficulty of translation and the demanding task that theologians and other scholars have in understanding the context of scripture and Pauline theology in general, and in particular, 1 Corinthians 6:9-10. Professor of Theology, Murray Rae of the University of Otago remarks: “...the translation of arsenokoitai is notoriously difficult, not least because the word has not been found in any other Greek text from Paul's era" (M. Rae, personal communication, April 25, 2018). With regard to both words, malakoi and arsenokoitai, Loader (2010) maintains: "[t]he meaning of both words is far from clear..." (p. 28).

While an exhaustive discussion around arsenokoitai and malakoi are beyond the scope of this paper, and indeed, beyond my abilities as a novice scholar researching on the fringes of theology, it will suffice to argue that since translation of the word arsenokoitai is problematic for trained theologians and scholars, it must follow that an untrained person, including of course myself, would fail to understand, with any depth, the meaning of the word and indeed the entire passage. By this logic, Israel Folau, trained to the highest levels in his chosen sport, but without any theological training to speak of, has uncritically quoted scripture to justify his view, based on a literal reading, that homosexuals are destined for hell, because 
of their sexualities and behaviours, if they do not repent for who and what they are. His logic on this matter, therefore, is flawed.

\section{Some Pasifika responses with regard Christianity and Folau's usage of scripture}

Folau's recent Instagram remark was not the first time he caused controversy with his opinions on gay people. On 12 September 2017, Israel Folau (2017) tweeted the following statement: "I love and respect all people for who they are and their opinions. but [sic] personally, I will not support gay marriage" (n.p.). University of Washington scholar, Seuta'afili Patrick Thomsen (2017), whose work "...examines the power and process in which social norms govern the complex agency of intersectional minority groups" (Henry M. Jackson School of International Studies, University of Washington, 2018, n.p.), wrote a piece in response to Folau's tweet, titled: In defence of Pacific sexual minorities: Why Israel Folau is no hero. He argues:

For Pacific Islanders, the story of Christianity and how it came to dominate our islands is far more sinister than many of us realize, owing in part to a ruthlessly efficient pairing of Christian ideology and the forces of colonization. As a result, our Pacific communities have some of the most Christian conservative social norms on the planet, including our standards of dress, defloration ceremonies, no trading on Sundays and of course being anti-homosexual (Thomsen, 2017, n.p.).

With regard to the problem of biblical translation, Thomsen (2017) opines:

Since the dawn of white man's time, the gays have been persecuted in countless ways. So much so that sometimes it can be hard to figure out which 
way (or who) is top or bottom. Our exclusion and stigmatization often rooted in conservativism continually writes us off as abnormal, justified by the voracious appetite Christianity has in oppressing deviance from the heteronormative patriarchy. For the longest time, Christianity and its attitude toward othering and supressing homosexuality has relied on flimsy interpretation of passages from the bible whose logical application has been at best, ad hoc, and at worst, deliberately violent (n.p., emphasis added). ${ }^{2}$

In terms of Pasifika sexualities, cultural context and the Bible, he declares:

I'm sorry, but Jesus never said anything about homosexuality, neither did he mention mahu, vakasalewalewa, palopa, fa'afafine, akavaine, fakaleiti, fakafifini, and other forms of gender identity that fall outside the western gender binary in the Pacific because guess what? Jesus was a Jew who lived in the modern day Middle East, while our ancestors were traversing the world's greatest ocean.

2 With regard to religion, in general, religiosity has been found to be protective in terms of mental health (Wong, Rew \& Slaikeu, 2006), with lower levels of depression in adolescents (Cotton, Larkin, Hoopes, Cromer \& Rosenthal, 2005), and young adults (Taliaferro, Rienzo, Pigg, Miller \& Dodd, 2009), and lower rates of suicidality in adolescents (Rew, Thomas, Horner, Resnick \& Beuhring, 2001) and young adults (Taliaferro, Rienzo, Pigg, Miller \& Dodd, 2009). However, there are strong connections between religiosity and negative views of homosexuality (Rowatt, LaBouff, Johnson, Froese $\&$ Tsang, 2009), and higher rates of internalised homophobia (Barnes \& Meyer, 2012; Kralovec, Fartacek, Fartacek \& Plöderl, 2014; Shilo \& Savaya, 2012), and internalised homophobia is associated with poor mental health outcomes (Kralovec et al., 2014; Shilo et al., 2012). 


\section{The bible does not have the range to speak on such matters, and neither does Israel Folau} (Thomsen, 2017, n.p., emphasis added).

A frequent response to Folau's stand on marriage equality in 2017, and also his statement about gay people and hell in 2018, is the notion that freedom of speech allows him to speak as he wishes. As regards freedom of speech in the context of Folau's 2017 Twitter comment, Thomsen (2017) opines:

Freedom of speech doesn't preclude you from critique, even if you claim to be protecting a religious community, one that is clearly not under threat in this case. And one, may I remind everyone, that has committed some heinous crimes of abuse, torture, waged wars in its name and helped decimate indigenous people across the globe. Sure, have an opinion, but make sure it's an informed one (Thomsen, 2017 , n.p.).

With regard to Israel Folau and freedom of speech, the Reverend Apelu Tielu (2018), minister for the Papakura Pacific Islander's Presbyterian Church, in his online article titled, Israel Folau and God's plan for gay people, states:

...the right to say what we want comes with responsibilities. Freedom is not without limits. In this case, Israel is irresponsible for not taking the time to consider the likely adverse effects of his comments on vulnerable people - and it appears he hasn't taken the time to reflect on his status in wider society, and how his words and actions would impact on his fans (Tielu, 2018, n.p.).

In supporting Pasifika young people from minority sexualities, Thomsen (2017) insists: 
Pacific queer youth need to know that they have a right to live in their truth, one that isn't shaped by ignorance and fake allyship. Folau had the opportunity to show true bravery in standing up for a community that he has in the past said to have supported in their quest for human rights. Instead he chose to maintain his position as the bible poster child by selling out sexual minorities. There is nothing brave about what he has done. I know Drag Queens with far more moral conviction (Thomsen, 2017, n.p.).

In an online response to Israel Folau titled, Dear Israel Folau your unchristian comments hurt young, vulnerable Pasifika, Tuiloma Lina Samu (2018), supported by 57 others, ${ }^{3}$ writes:

The sad thing is we can't deny that many of our people are entrenched in this unforgiving, (un)Christian conditioning and agree with you. The mistranslation and misuse of Bible scripture is the biggest impediment to Pasifika Rainbow people being able to live our lives without fear,

3 The supporters were named in the article as follows: Tanu Gago, Resitara Apa, Phylesha Brown-Acton, Joey Joleen Mataele, Fia'ailetoa Ken Moala, Phineas Hartson, Pesetā Betty Sio, Lealailepule Edward "Buckwheat" Cowley, JD Victor, Leuli Eshraghi, Iakopo Tologata, Sonya Apa Temata, Robbie Kainuku, Tim Swann, Tim Baice, Lindah Lepou, Walter Kawika'iulani Aipa and Herbee Bartley, Jaycee Tanuvasa, Va'inetuta'i Richard, Alan J Wendt, Nick Netzler, Darren Taniue, Torranice Campbel, Dee Fa'aea-Aiono, Robert Oliver, Angelyse-Heitiare Armstrong, Tuafale Tanoa'i, Teokota'i Paitai, Siaosi Mulipola, Yuki Kihara, Michael Gullery, Ana Te Whaiti, Paul Fagamalo, Cathryn Laban, Dr Clive Aspin, Associate Professor Leonie Pihama, Monise Fata-Meafou, Jaye Moors, Harold Samu, Olivia Taouma, Lisa Taouma, Erina Rewita Leauanae, Faumui Lope Ginnen, Faiva Holmes, Aruna PoChing, Amanda Moors Mailei, Lani Wendt Young, Rhia Taonui, Malia Manuleleua Tua’i, Reverend Mua Strickson-Pua, Nina Milne, Pesetā Eunice Sio, Rena Mahauariki, Richard Shortland Cooper, Agnes Rasmussen, Melissa Lama, Danielle O’Halloran, Christine Robertson-Ammunson 
backlash and hatred from those who often matter the most to us (Samu, 2018, n.p., emphasis added).

Vui-Talitu (2018), in an article titled, NZ's Pacific community reacts to Folau's anti-gay comments, reports that there have been a range of responses from the Pasifika community reacting to Folau's comments on gay people. Henry Aho, president of Tonga's Fakaleiti Association opines:

If your belief is going to lead to people getting discriminated against or your doctrinal interpretations is going to lead to people being suicidal, being cast out of their own families, so it is important to revisit their beliefs to tap into their own humanity [sic] (Vui-Talitu, 2018, n.p., emphasis added).

The Reverend Mua Strickson-Pua states that he is disappointed in Folau's theology and comments, arguing instead for an inclusive Christianity, "[t]hat it is not about condemning people or putting them in a box or sending people to places called hell. It is about how do we actually live the practise of our faith, the examples of our saviour?" (Vui-Talitu, 2018, n.p., emphasis added).

With regard to the links between Pauline theology and the Folau controversy, Tielu (2018) argues:

The Christianity of judgment and condemnation is very much the creation of the apostle Paul. It reflects his background as a Pharisee.

Paul, who wrote the 1 Corinthians 6:9-10 verse that Israel quoted, struggled throughout his ministry to reconcile the Pharisaic principles of 
being God's moral police, and the exclusion of those who didn't make the moral cut, with Jesus' inclusive and unconditional love for the sinner.

\begin{abstract}
People love Paul's theology, because it makes them feel good. But they don't realise that by passing judgment on others, they're also condemning themselves - for we all have sinned. Christians are not God's moral police, because Christianity is not about living a moral life. Christianity is about living a divine life - living life as if we are Jesus the Christ of God. This life offers life to others. It's a life of love in words and deeds. It's a life lived for others. By not offering love to the vulnerable and the "little ones" that Jesus loved, the Folaus have condemned themselves (n.p., emphasis added).
\end{abstract}

Tielu (2018) hopes that lessons may be learned from the Israel Folau controversy and asserts:

Take time to think through your actions and words, and leave biblical interpretation to those trained for the task. The issue of homosexuals in the Bible is complex, and is highly misconstrued and misunderstood. But Jesus is the point of reference if you need some insights. Offer love, not judgment and condemnation - that's the key value of the Christian faith. Be Christ to those you meet in your journey of life (n.p., emphasis added).

With regard to Israel and Maria's untrained used of the Bible, Tielu (2018) affirms:

Writers and speakers must take responsibility for how their words might be construed. They should also 
know that they have no control on how people might interpret their words. Nor can they hide behind the fact that Israel was only quoting from the Bible. Once we appropriate words by others, those words become ours. Both Israel and Maria have shown immaturity in their reckless use - or abuse - of the Bible (n.p., emphasis added).

In the spirit of reconciliation, Tielu (2018) appeals to the Folau's to make amends with those that have been hurt:

I hope that people will forgive the Folaus, but $I$ also hope the Folaus will recognise the flaws of their position and the harm they might have caused and apologise to those they've victimised (Tielu, 2018, n.p., emphasis added).

In a video by Tagata Pasifika (2018) titled, Pacific perspectives on the Israel Folau controversy, Pulotu-Endemann claims that views such as those expressed by Folau, come from a theology that was imported into the Pacific and reflects the cultural and theological views, at that time, of the missionaries that brought Christianity to Polynesia. As people become more informed and educated, Pulotu-Endemann claims, our views should change in light of new knowledge (Tagata Pasifika, 2018). In response to the notion of a literal understanding of 1 Corinthians 6:9-10, used by Israel Folau to justify his beliefs, the Reverend Ali'itasi Aoina-Salesa - a minister of the Methodist Church of New Zealand, featured in the same video states: "I live my life by the two commandments: to love God and to love my neighbour; the command comes not with quantifications or qualification, it doesn't say "love my neighbour only if they're Tongan" or "love my neighbour only if they are the same gender, or same faith, or belief, or sexual orientation". The command is to love" (Tagata Pasifika, 2018, n.p.). 


\section{The potential impacts of Israel Folau's comments minority sexualities}

Referring to Israel Folau's 2017 Twitter comment where he stated that he did not support gay marriage, despite claiming to love and respect others, Thomsen (2017) opines:

If you're lucky enough to make it out of adolescence, somehow relatively unscathed, the best one can hope for is that the progression of one abusive and violent experience after another will enable you to wear a cloak of resilience that inoculates you against the ignorance of this world. I know we have all heard the statistics, they vary from country to country, but the overall trend stays the same no matter where in the world you are. LGBTQI+ teens are far more likely to self-harm than heterosexual teens (Thomsen, 2017, n.p.).

Lucassen, Merry, Robinson, Denny, Clark, Ameratunga, Crengle and Rossen's (2011) article, Sexual attraction, depression, self-harm, suicidality and help-seeking behaviour in New Zealand secondary school students, contends that young people who are attracted to their own sex, and those attracted to both sexes, are vulnerable to significant mental health disparities in terms of depression, self-harm, suicidality and help-seeking behaviour. Indeed, the international research clearly shows that lesbian, gay, bisexual men and women, and transgender people experience poorer levels of mental health than do heterosexuals (Adams, Dickinson, Asiasiga, 2013; Hatzenbuchler, 2010; Herek, 2009; Meyer, 2016). These young people are at disproportionately higher risk of suffering abuse and distress (Gibbs, 2015). They experience higher levels of victimisation, bullying and abuse than do their heterosexual counterparts (Friedman, Marshal, Guadamuz, Wei, Wong, 
Saewyc \& Stall, 2011). LGBT adolescents are also at greater risk, compared with their heterosexual peers, of experiencing mental illness (King, Semlyen, Tai, Killaspy, Osborn, Popelyuk \& Nazareth, 2008; Lewis, 2009; Mustanski, Garofalo \& Emerson, 2010), suicidal thoughts (Almeida, Johnson, Corliss, Molnar \& Azrael, 2009; King et al., 2008; Lewis, 2009), and self-harm (Almeida et al., 2009; King et al., 2008). In Self harm and suicide risk for same-sex attracted young people: A family perspective, Brown (2002) argues that young people who are same-sex attracted experience victimisation, harassment and abuse because of their sexual identity. Those who are open about their sexuality often experience abuse and rejection by family and friends, and as a consequence, feel unsafe about exposing their sexuality, choosing instead, to conceal their feelings (Brown, 2002). This reticence may result in self-harming behaviours including substance abuse, random and unsafe sexual practices, running away and suicide (Brown, 2002). Societal ignorance, prejudice and discrimination are crucial causative factors to continuing marginalisation and isolation of same-sex attracted young people (Brown, 2002). Tragically, LGBT youth are five times more likely to experience suicidal thoughts (Almeida et al., 2009), and LGB adolescents are five time more likely to report an attempted suicide (Hatzenbuehler, 2011). As well, $25 \%$ to $32 \%$ of transgender youth have attempted suicide (Clements-Nolle, Marx \& Katz, 2006; Grossman \& D'Augelli, 2007).

Minority stress theory argues that minority groups suffer from higher levels of stress, and that LGBT people, in particular, suffer stressors that are directly related to their sexuality which may result in negative mental health outcomes (Hatzenbuehler, Hilt, \& Nolen-Hoeksema, 2010; Mays, Cochran \& Barnes, 2007; Meyer, 2003). The minority-stress-related risk factors for LGBT adolescents include: negative events such as discrimination and victimisation; negative views of homosexuality; internalised anxiety about sexual and/or gender identity; and emotional distress connected to acceptance/rejection (Kelleher, 2009; 
Rosario, Rotheram-Borus \& Reid, 1996; Rosario, Schrimshaw, Hunter \& Gwadz, 2002). Indeed, a number of studies have linked minority-stress with suicidal behaviours among LGBT adolescents (Mays \& Cochran, 2001; Russell, 2003; Ryan, Huebner, Diaz \& Sanchez, 2009; Savin-Williams \& Ream, 2003).

With regard to gay youth suicide in Aotearoa New Zealand, in their article, Life on the seesaw: A qualitative study of suicide resiliency factors for young gay men, Fenaughty and Harré (2003) argue that important factors in resilience for gay youth and protecting against suicide is identification with positive role models, positive social norms and conditions, support groups, positive LBG representations, high self-esteem, and high levels of support and acceptance from family, peers and schools. Conversely, heterosexism, social isolation, bullying, HIV anxiety, depression, internalised homophobia, rejection and loneliness, substance abuse and social withdrawal are considered to be well-known risk factors for gay youth (Fenaughty \& Harré, 2003). Fenaughty and Harré's (2003) Seesaw Model of Bisexual and Gay Male Suicide (below), shows that finding a balance between these positive and negative factors may reveal solutions for gay suicide. They state: "Depending on the balance of these factors, youth might either be resilient, attempt suicide, or teeter somewhere in between" (Fenaughty \& Harré, 2003, p. 1). Fenaughty and Harré's (2003) model shows the potential power that role models like Israel Folau may have in the lives of bisexual and gay young men. 


\section{Figure 1: The Seesaw Model of Bisexual and Gay Male Suicide}

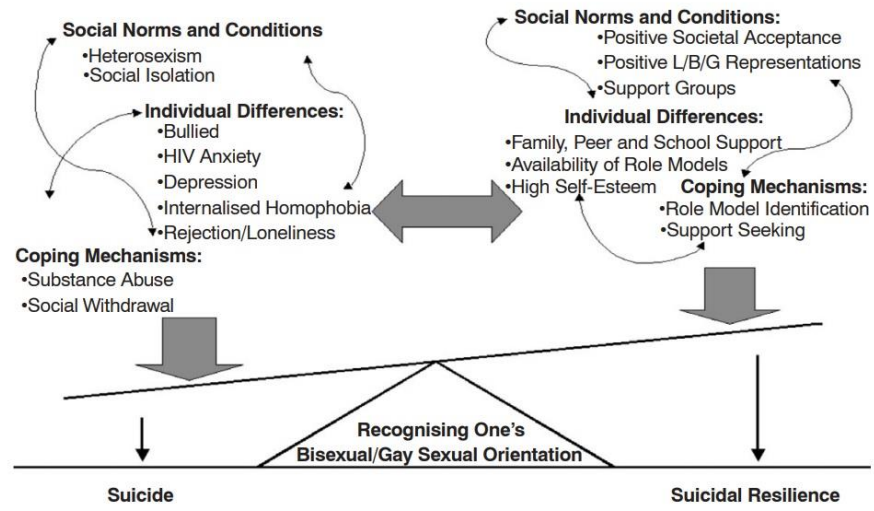

(Fenaughty \& Harré, 2003, p. 17).

In a New Zealand Herald article titled, Israel Folau comments 'incredibly dangerous', Labour Minister of Parliament and former Black Fern, Louisa Wall, of Māori descent, orates:

His comments are incredibly dangerous because essentially what he's saying if you're a young LGBTI person is that that identity is bad, it's wrong. And you should repent. Which is to denounce it. Because if you don't, you're going to suffer for the rest of your life.

Obviously in New Zealand we're 32 years now passed homosexual law reform. Just the other day we've expunged the historical convictions of about 1,000 men who were caught by laws that basically said 'if you were a young gay person, you were a criminal'. 
I think we live in this enlightened era where we accept everybody for who they are including their sexual orientation and identity. But the biggest issue for me is if you're a young LGBTI person, we already know through research, you're four times more likely to self-harm and to attempt suicide. So when people like Israel Folau, with such a massive influence on society, he's got over 330,000 followers on his Instagram account, say what they do, it actually creates a really unsafe environment for our young people.

Even though Israel said he was quoting from the Bible, I think what I'd ask him to do is to think about the influence that he has. Obviously the platform that he has to spread what he has to say and how negative that impact is on particularly young LGBTI people. If you're a minister and you say that in a church on a Sunday, you're preaching to the converted. He's not preaching to the converted he's preaching to a whole lot of people. A range of people who love rugby, who love Israel. That also includes young people who are incredibly vulnerable, they need their identity reinforced and they need to be supported through what is a harrowing journey if you're finding out you're a young gay person today and if role models like Israel Folau don't support our young people to be who they are then actually $I$ think are suicide statistics highlight the issues we have as a society (New Zealand Herald, 2018, April 18, n.p., emphasis added). 
Pasifika Advisor for the New Zealand Human Rights Commission, Tuiloma Lina Samu argues that Israel Folau should be held accountable for what he has said:

In 2018 intolerance against people who identify as rainbow, gay, bisexual or transgender even our faafafine, fafatama, our akava'ine, fakaleiti, fakafaafine communities, it is not acceptable and intolerance and speech that could be very hurtful has to be challenged (Vui-Talitu, 2018, n.p., emphasis added).

Writing directly to Israel Folau in, Dear Israel Folau - your unchristian comments hurt young, vulnerable Pasifika, with regard to Pasifika LGBTQI, Samu (2018) states:

Our youth suicide rates are the highest in the "developed" world and Pasifika who identify as LGBTQI+ are a significant number of those souls who take their own lives because of the intolerance, rejection and hatred from our own loved ones. While we like to think our Pasifika peoples are some of the most loving of all, you have highlighted that this is often not the case when it comes to LGBTQI+ peoples. (n.p., emphasis added)

With regard to the impacts of Folau's position on sexual minorities, Tielu (2018) opines:

When I first saw Israel's comments, I cringed. I wished he had never made them. First, because they could have consequences for gay people. Second, because they don't represent the core values of the Christian faith and the primary message of Jesus. And third, because Israel's 
comments may not reflect who he really is (Tielu, 2018, n.p., emphasis added).

Tielu (2018) continues:

Israel and Maria Folau are probably the biggest stars in their respective sports - rugby in Australia and netball in New Zealand. As such, they're role models for aspiring young rugby and netball players, especially in the Pacific Islands community. Their fans look up to them, whether they like it or not. It's a responsibility they have tacitly accepted by playing their sports at the highest level.

On the other hand, gay people are perhaps the most maligned people in our society. And while some have developed confidence and strength in themselves and their sexuality, I suspect the majority are fragile and vulnerable. Condemnations of their beings by their role models could have lethal consequences for some, especially the youngsters. This is something that the Folaus might not have known. If they knew, but didn't care, that would be very sad and very un-Christian (n.p., emphasis added).

In encouraging Pasifika sexual minorities, Pulotu-Endemann argues that to allow oneself to be hurt by the opinions of others, such as those of Israel Folau, is to give power to those opinions and to put oneself at risk of receding into a "dark space", and that, ultimately, it is more empowering to operate from a place of love and forgiveness (Tagata Pasifika, 2018). PulotuEndemann also maintains that Folau's comments may negatively impact upon those who are vulnerable (Tagata Pasifika, 2018). In particular, Pulotu-Endemann is concerned about the impacts that the discourse expressed by Folau - being 
highly influential and considered to be a role model for many will have on young people coming to terms with their sexual identities and the implications for their wellbeing (Tagata Pasifika, 2018).

Deputy Leader of the New Zealand National Party, the Honourable Paula Bennett, of Māori heritage, has commented on Folau's remarks, stating that someone in his position needs to consider the effect of his words on young people (Satherley, 2018). She argues:

Young people are going through changes and thinking about their sexuality, and he might be someone they look up to. To hear something like that I think can have a chilling effect on them.

If there's any of them out there listening, I want them to know that there's a whole lot of us who just go, 'Good luck whoever you are, and whoever you may fall in love with is perfectly acceptable. It doesn't matter. We just wish you lots of love and a good life.'

I'm not sure I do respect his right to say something like that when it could be extremely harmful to some people out there who don't quite have the maturity to see it as one person's view (Satherley, 2018, n.p., emphasis added).

In an article titled, Sir Michael calls for 'love and grace' from Folau, All Blacks legend, Sir La'auli Savae Michael Jones ${ }^{4}$ states:

4 The style of Sir Michael's name, incorporating his Sāmoan titles, was taken from Samoa Observer (2017). 
In terms of my faith it's very much a faith built on love and grace. There are members of my family from the (gay) community and we love them very much and they are an integral part of our lives and they are a big part of who we are.

Being able to express yourself is important but (it needs to be done) respectfully and with wisdom (n.p.).

In a New Zealand Herald story titled, All Blacks and Black Ferns launch diversity campaign labelling 'discrimination' as enemy, it was announced that the All Blacks and Black Ferns had made a very powerful stand in a video as part of their diversity is strength campaign (New Zealand Herald, 2018, April 23). In this video the values of the teams are expressed, thusly:

The next "battle" and "enemy" was devious and truly formidable, the video said.

"It is discrimination - an enemy that cannot be fought alone and must be defeated together.

"It will take more than 15 - it will take thousands millions"

The video shows the All Black and Black Ferns squads travelling to a rugby stadium in Osaka, Japan.

Several moments in the video show the rainbow colours of the LGBT flag on the strips of the players, on jet trails, and by supporters waving the flag (New Zealand Herald, 2018, April 23, n.p.).

This article has argued that biblical interpretation by the untrained is problematic. Without theological training and 
adequate background knowledge, the biblical context is bewildering. The example of the word arsenokoitai - the word upon which Folau's argument rests - is extremely difficult to understand and interpret, as it is the only time that the word appears (except again in 1 Timothy 1:10) in Greek literature. Without a working knowledge of biblical Greek, and knowledge of the politics and culture of Paul's time, it would be impossible for Folau to extract even the most rudimentary exegesis from 1 Corinthians 6:9-10. Furthermore, making claims such as those made by Folau are also, as Louisa Wall has noted, extremely dangerous, especially to young LGBTQI+ people. Research around mental health and suicide statistics for LGBTQI+ young people are depressing. The literature shows that LGBTQI+ young people are disproportionately more at risk of mental health issues including depression, self-harm and suicide. Fenaughty and Harré (2003) reveal that positive role models contribute significantly to suicide resilience for gay and bisexual men. A sports star like Israel Folau is highly influential. His words are powerful. He may choose to use his words to breathe life into the lives of the downtrodden, or to expel them into the depths of despair. The Israel Folau controversy is a timely reminder to us all, to think more about what we say and how we say it, and to consider the implications of our words and actions. All Black T. J. Perenara has commented on Twitter, in support of LGBTQI+, and in particular to Māori and Pasifika LGBTQI+ people, thusly:

To anyone, young Māori/Pasifika people especially, who may be struggling with their identity - please know that it is ok to be you. You are perfect as you are. Do not let these comments keep you from being yourself. Polynesia has been sexually diverse since forever. Tj Perenara (2018 [Tweet]. 


\section{Bibliography}

Adams, J., Dickinson, P. \& Asiasiga, L. (2013). Mental health issues for lesbian, gay, bisexual and transgender people: A qualitative study. International Journal of Mental Health Promotion, 15(2), 105-120.

Almeida, J., Johnson, R. M., Corliss, H. L., Molnar, B. E. \& Azrael, D. (2009). Emotional distress among LGBT youth: the influence of perceived discrimination based on sexual orientation. Journal of Youth and Adolescence, 38(7), 10011014.

Barnes, D. M. \& Meyer, I. H. (2012). Religious affiliation, internalized homophobia, and mental health in lesbians, gay men, and bisexuals. American Journal of Orthopsychiatry, 82(4), 505-15.

Boswell, J. (1980). Christianity, social intolerance and homosexuality: Gay people in Western Europe from the beginnings of the Christian era to the Fourteenth Century. Chicago, ILL: University of Chicago Press.

Boswell, J. (1994). Same-sex unions in premodern Europe. New York, NY: Villard Books.

Brooten, B. J. (1996). Love between women: Early Christian responses to female homoeroticism. Chicago, IL: The University of Chicago Press.

Brown, R. (2002). Self harm and suicide risk for same-sex attracted young people: A family perspective. Australian eJournal for the Advancement of Mental Health, 1(1), 9-19. Retrieved from: https://www-tandfonlinecom.ezproxy.otago.ac.nz/doi/pdf/ 10.5172/jamh.1.1.9

Cannon, J. R. (2005). The Bible, Christianity and homosexuality. Retrieved http://www.psa91.com/resource/bible_homo.pdf

Clements-Nolle, K. Marx, R. \& Katz, M. (2006).Attempted suicide among transgender persons: The influence of gender-based discrimination and victimization. Journal of Homosexuality, 51(3), 53-69.

Cotton, S., Larkin, E., Hoopes, A., Cromer, B. A. \& Rosenthal, S. L. (2005). The impact of adolescent spirituality on depressive symptoms and health risk behaviors. Journal of Adolescent Health, 36(6), 529.

Countryman, L. W. (1988). Dirt, greed and sex: Sexual ethics in the New Testament and their implications for today. Philadelphia, PA: Fortress Press. 
Elliot, J. H. (2004). No Kingdom of God for softies? or, what was Paul really saying? 1 Corinthians 6:9-10 in context. Biblical Theology Bulletin: Journal of Bible and Culture, 34(1), 17-40.

Fenaughty, J. \& Harré, N. (2003). Life on the seesaw: A qualitative study of suicide resiliency factors for young gay men. Journal of Homosexuality, 45(1), 1-22. Retrieved from: https://www-tandfonlinecom.ezproxy.otago.ac.nz/doi/pdf/10.1300/J082v45n01_0 1

Folau, I. (16 April, 2018). I'm a sinner too. Retrieved from: https://www.playersvoice.com.au/israel-folau-im-asinner-too/

Friedman, M. S., Marshal, M. P., Guadamuz, T. E., Wei, C., Wong, C. F., Saewyc, E. \& Stall, R. (2011). A meta-analysis of disparities in childhood sexual abuse, parental physical abuse, and peer victimization among sexual minority and sexual nonminority individuals, American Journal of Public Health, 101(8), 1481-1494.

Gibbs, J. J. (2015). Religious conflict, sexual identity, and suicidal behaviours among LGBT young adults. Archives of Suicide Research, 19(4), 472-488.

Grossman, A. H. \& D'Augelli, A. R. (2007). Transgender youth and life-threatening behaviors. Suicide and Life-Threatening Behavior, 37(5), 527-37.

Hatzenbuehler, M. L. (2010). Social factors as determinants of mental health disparities in LBG populations: Implications for public policy. Social Issues and Policy Review, 4(1), 3162.

Hatzenbuehler, M. L. (2011). The social environment and suicide attempts in lesbian, gay, and bisexual youth. Pediatrics, 127(5), 896-903.

Hatzenbuehler, M. L., Hilt, L. M. \& Nolen-Hoeksema S. (2010). Gender, sexual orientation, and vulnerability to depression. In J. Chrisler \& D. McCreary (eds.), Handbook of Gender Research in Psychology (pp. 133-152). New York, NY: Springer.

Helminiak, D. A. (2000). What the Bible really says about homosexuality. Tajique, NM: Alamo Square Press.

Henry M. Jackson School of International Studies, University of Washington (2018). Patrick Thomsen. Retrieved from: https://jsis.washington.edu/people/patrick-thomsen/

Herek, G. M. (2009). Sexual stigma and sexual prejudice in the United States: A conceptual framework. In Contemporary 
perspectives on lesbian, gay, and bisexual identities (pp. 65111). New York, NY: Springer.

Israel Folau (2018, September 12). I love and respect all people for who they are and their opinions. but personally, I will not support gay marriage [Tweet]. Retrieved from: https://twitter.com/IzzyFolau/status/907820304352890 880

Lewis, N. M. (2009). Mental health in sexual minorities: recent indicators, trends, and their relationships to place in North America and Europe. Health and Place, 15(4), 1029-1045.

Lucassen, M. F. G., Merry, S. N., Robinson, E. M., Denny, S., Clark, T., Ameratunga, S., Crengle, S. \& Rossen, F. V. (2011). Sexual attraction, depression, self-harm, suicidality and help-seeking behaviour in New Zealand secondary school students. Australian and New Zealand Journal of Psychiatry, 45(5), 376-383.

Jewett, R. (2007). Romans. Minneapolis, MN: Fortress.

Kelleher, C. (2009). Minority stress and health: Implications for lesbian, gay, bisexual, transgender, and questioning (LGBTQ) young people. Counseling Psychology Quarterly, 22(4), 373-379.

King, M., Semlyen, J., Tai, S. S., Killaspy, H., Osborn, D., Popelyuk, D \& Nazareth, I. (2008). A systematic review of mental disorder, suicide, and deliberate self harm in lesbian, gay and bisexual people. BMC Psychiatry, 8, 70.

Kralovec, K., Fartacek, C., Fartacek R. \& Plöderl, M. (2014). Religion and suicide risk in lesbian, gay and bisexual Austrians. Journal of Religion and Health, 53(2), 413-23.

Lehrer, M. (2002). What does the Bible say about homosexuality: An exercise in biblical hermeneutics. Denison Journal of Religion, 2(6), 62-75.

Loader, W. (2010). Sexuality in the New Testament: Understanding the key texts. Louisville, KY: Westminster John Knox Press.

Malick, D. E. (1993). The condemnation of homosexuality in 1 Corinthians 6:9. Bibliotheca Sacra, 150(600), 479-492.

Martin, D. B. (2006). Paul without passion: On Paul's rejection of desire in sex and marriage. In D. B. Martin, Sex and the single Savior: Gender and sexuality in biblical interpretation (pp. 65-76). Louisville, TN: Westminster John Knox.

Mays, V. M. \& Cochran, S. D. (2001). Mental health correlates of perceived discrimination among lesbian, gay, and 
bisexual adults in the United States. American Journal of Public Health, 91(11), 1869-1876.

Mays, V. M., Cochran, S. D. \& Barnes, N. W. (2007). Race, racebased discrimination, and health outcomes among African Americans. Annual Review of Psychology, 58, 201-25.

Meyer, I. H. (2003). Prejudice, social stress, and mental health in lesbian, gay, and bisexual populations: conceptual issues and research evidence. Psychological Bulletin, 129(5), 674697.

Meyer, I. H. (2016). Does an improved social environment for sexual and gender minorities have implications for a new minority stress research agenda? Psychology of Sexualities Review, 7(1), 81-90.

Mustanski, B. S., Garofalo, R. \& Emerson, E. M. (2010). Mental health disorders, psychological distress, and suicidality in a diverse sample of lesbian, gay, bisexual, and transgender youths. American Journal of Public Health, 100(12), 24262432.

New Zealand Herald (2018, April 18). Israel Folau comments 'extremely dangerous' - Louisa Wall. Retrieved from: http://www.nzherald.co.nz/sport/news/article.cfm?c_id= 4\&objectid $=12034701$

New Zealand Herald (2018, April 23). All Blacks and Black Ferns launch diversity campaign labelling 'discrimination' as enemy. Retrieved from: https://www.nzherald.co.nz/sport/news/article.cfm?c_id= 4\&objectid $=12038144$

Peters, B. (2018, April 25). Bringing some balance to Israel Folau's reading about homosexuals. Retrieved from: http:/ / liturgy.co.nz/bringing-some-balance-to-israelfolaus-reading-about-homosexuals

Tj Perenara (2018, April 18). To anyone, young Māori/Pasifika people especially, who may be struggling with their identity - please know that it is ok to be you. You are perfect as you are. Do not let these comments keep you from being yourself. Polynesia has been sexually diverse since forever [Tweet]. Retrieved from: https://twitter.com/Tj_Perenara/status/98652325160922 7266

Radio New Zealand (2018, April 19). Sir Michael calls for 'love and grace' from Folau. Retrieved from: https://www.radionz.co.nz/news/sport/355491/sirmichael-calls-for-love-and-grace-from-folau 
Rosario, M., Rotheram-Borus, M. J. \& Reid, H. (1996). Gayrelated stress and its correlates among gay and bisexual male adolescents of predominantly black and Hispanic background. Journal of Community Psychology, 24(2), 136159.

Rosario, M., Schrimshaw, E. W., Hunter, J. \& Gwadz, M. (2002). Gay-related stress and emotional distress among gay, lesbian, and bisexual youths: a longitudinal examination. Journal of Consulting and Clinical Psychology, 70(4), 96775.

Rasmussen, M. L., Sanjakdar, F., Allen, L., Quinlivan, K. \& Bromdal, A. (2017). Homophobia, transphobia, young people and the question of responsibility. Discourse: Studies in the Cultural Politics of Education, 38(1), 30-42. Retrieved from: https://www-tandfonlinecom.ezproxy.otago.ac.nz/doi/pdf/10.1080/01596306.201 5.1104850 ? needAccess $=$ true

Rew, L., Thomas, N., Horner, S. D., Resnick, M. D. \& Beuhring, T. (2001). Correlates of recent suicide attempts in a triethnic group of adolescents. Journal of Nursing Scholarship, 33(4), 361-7.

Robinson, G. (2018, April 4). Israel Folau sparks controversy by saying God's plan for gay people is ' $H E L L$ '. Retrieved from: https://www.smh.com.au/sport/rugby-union/israelfolau-sparks-controversy-by-saying-god-s-plan-for-gaypeople-is-hell-20180404-p4z7rd.html

Rowatt, W. C., LaBouff, J., Johnson. M., Froese, P. \& Tsang, J. (2009). Associations among religiousness, social attitudes, and prejudice in a national sample of American adults. Psychology of Religion and Spirituality, 1, 14-24.

Russell, S. T. (2003). Sexual minority youth and suicide risk. American Behavioral Scientist, 46, 1241-1257.

Ryanm, C., Huebner, D., Diaz, R. M. \& Sanchez, J. (2009). Family rejection as a predictor of negative health outcomes in white and Latino lesbian, gay, and bisexual young adults. Pediatrics, 123(1), 346-52.

Samoa Observer (2017, June 4). 'I'm a product of a village'. Retrieved from: http://www.samoaobserver.ws/en/05_06_2017/sport/20 731/'I'm-a-product-of-a-village'---Sir-Laauli-MichaelJones.htm

Samu, T. L. (2018, April 10). Dear Israel Folau - your unchristian comments hurt, young, vulnerable Pasifika. Retrieved from: 
https://thespinoff.co.nz/society/10-04-2018/dear-israelfalou-your-unchristian-comments-hurt-young-vulnerablepasifika/

Satherley, D. (2018, April 23). Israel Folau fallout: No need for stronger hate speech laws - Paula Bennett. Retrieved from: http://www.newshub.co.nz/home/politics/2018/04/israe 1-folau-fallout-no-need-for-stronger-hate-speech-lawspaula-bennett.html

Savin-Williams, R. C. \& Ream, G. L. (2003). Suicide attempts among sexual-minority male youth. Journal of Clinical Child Adolescent Psychology, 32(4), 509-22.

Scroggs, R. (1983). Homosexuality in the New Testament: Contextual background for contemporary debate. Philadelphia, PA: Fortress Press.

Shilo, G. \& Savaya, R. (2012). Mental health of lesbian, gay, and bisexual youth and young adults: Differential effects of age, gender, religiousity, and sexual orientation. Journal of Research on Adolescence, 22(2), 310-325.

Tagata Pasifika (2018, April 20). Pacific perspectives on the Israel Folau controversy. Retrieved from: https: / / www.youtube.com/watch?v $=n L 1 z W n z c S u 8$

Taliaferro, L. A., Rienzo, B. A., Pigg, R. M. Jr., Miller, M. D. \& Dodd, V. J. (2009). Spiritual well-being and suicidal ideation among college students. Journal of American College Health, 58(1), 83-90.

Thomsen, P. (2017, September 20). In defence of Pacific sexual minorities: Why Israel Folau is no hero. Retrieved from: http://pantograph-punch.com/post/why-israel-folau-isno-hero

Tielu, A. (2018, April 22). Israel Folau and God's plan for gay people. Retrieved from: https://etangata.co.nz/news/israel-folau-and-gods-plan-for-gaypeople

Treharne, G. J. \& Adams, J. (2017). Critical perspectives on the diversity of research into sexualities and health in Aotearoa/New Zealand: Thinking outside the boxes. Psychology of Sexualities Review, 8(1), 53-70. Retrieved from:

https://www.researchgate.net/publication/316984757_Cr itical_perspectives_on_the_diversity_of_research_into_sexu alities_and_health_in_AotearoaNew_Zealand_Thinking_out side_the_boxes 
Velotta, J. R. (2010, March). Who are the arsenokoitai which are excluded from the Kingdom of God in 1 Corinthians 6:9? A paper presented to the Faculty of Temple Baptist Seminary, Brownsville, TN.

Vui-Talitu, S. (2018, April 20). NZ's Pacific community reacts to Folau's anti-gay comments. Retrieved from: https://www.radionz.co.nz/international/pacificnews/355599/nz-s-pacific-community-reacts-to-folau-santi-gay-comments

Wong, Y. J., Rew, L. \& Slaikeu, K. D. (2006). A systematic review of recent research on adolescent religiosity/spirituality and mental health. Issues in Mental Health Nursing, 27(2), 16183. 